\title{
Az „új artikulál(hat)atlanság” Az utópikus elsorvadása a „posztideologikus” korszak hajnalán Jürgen Habermas Die Neue Unübersichtlichkeit c. könyvében ${ }^{1}$
}

\section{The 'New Inarticulateness'. The Atrophy of the Utopian at the Dawn of the 'Postideological' Age in Die Neue Unübersichtlichkeit of Jürgen Habermas}

\author{
Tillmann Ármin \\ ELTE mesterszakos hallgató \\ tillmann.armin@gmail.com
}

Initially submitted March 19, 2020; accepted for publication Apr.28, 2020

\begin{abstract}
The hyperreal construction of Postmodernism, which was the key at the same time to the understanding of the Postmodern Condition, could be revealed only by the joint conceptual analysis of the history of ideas and society. In such an ahistorical and anti-memorial culture as Postmodernism, it is not a surprise that we are suffering under utopia- and existence-blindness: one must produce an alternative system, because criticising capitalism is, however inevitable, is not sufficient. Habermas, in his brilliant essay, briefly depicts the structural change of the Western Utopian tradition concerning the temporal and historical view through the centuries. The analysis connects with the in-depth examination of working mechanisms of the welfare state based on the idealised working society. Habermas detects the internal contradictions of the welfare state that surfaced in the 1970s and which by the 1980s proved unsustainable. Capitalism can neither be tamed nor maintained by reforms and crisis management, instead of these, the Western societies, in favour of their existence, must be able to redefine the terms of labour; as well as the social institutions and life forms that are based and shaped by its point of view. Thus, the task of the coming social politics - i.e. the fight for definitions - is twofold. On the one hand, there have to be critically deconstructed the key terms of the repressive idealism of Postmodernism. On the other hand, every competing ideology should enforce in this way their redefined conceptual apparatuses.
\end{abstract}

Kulcsszavak: látszatneutralitás, posztisztikus fogalmak, represszív idealizmus, hiányzó rendszeralternatívák, utópiavakság, szimulákrumokhoz igazított valóság, ideologikus átértelmezések, önazonosság differencia által

Keywords: sham neutrality, postistical terms, repressive idealism, lacking system alternatives, utopia blindness, reality-adapted simulacra, ideological revaluations, self-identity through difference(s)

„Mindaz, ami utópiának érzödik, a fennállóval szemben megmarad negatívnak és a fennállóhoz tartozónak. [...] [A] megbékélés látszatát kibékíthetetlenül tagadva tartja meg

\footnotetext{
${ }^{1}$ Habermas elemzésem kiindulópontjául szolgáló tanulmánya magyarul A jóléti állam válsága és az utópikus energiák kimerülése címet viseli. A magyar nyelvü megjelenés helye: Jürgen Habermas: „A jóléti állam válsága és az utópikus energiák kimerülése". In: Válogatott tanulmányok. Fordította: Adamik Lajos, Bendl Júlia, Felkai Gábor. Budapest: Atlantisz 1994.
} 
Kaleidoscope

a megbékélést a békétlenség kellös közepén, helyes tudattal ismerve fel azt a korszakot, amelyben kiélezett módon [benne rejlik] az utópia reális lehetösége."

„A gazdaság megszünt, ám hiányzik a lélek, a hit, amelynek helyet kellene csinálni; a cselekvöen okos tekintet mindent lerombolt, sok mindent bizonyára joggal rombolt le, joggal rombolta le a szocializmus telepesei és szakadárjai dédelgette privát idilleket és semmit át nem fúró álmokat mind, azok idilljeit és álmait, akik a világ legjavából valamiféle szép mellékföldet szerettek volna lepárolni, és hagyták kicsapódni a maradék földgolyó nyákját, és bizonyára okkal dezavuáltatott a túlontúl árkádiai, az absztrakt utópikus szocializmus is, amely a reneszánsszal az ezeréves birodalom szekularizált változataként újból fölbukkant, és gyakran mint nagyon is józan osztálycélok és gazdasági forradalmak szubsztanciátlan drapériája, ideológiája bukkant föl újból. Ám ezzel sem a mindezekben ott rejlö utópikus törekvést nem értettük meg, sem csodatévö képeik szubsztanciáját nem ragadtuk és nem itélhettük meg, ahogy annak a vallásos ősvágynak sem mondtunk búcsút, amely hisz a világátépités minden rezdülésében és céljában, az életnek szeretett volna teret nyitni, hogy isteni módon átlényegüljön, hogy végre khiliasztikusan befészkelje magát jóságba, szabadságba, a fény teloszába."

„Csak egy érzelmileg telitett, majdhogynem politikai csatakiáltásban nyer értelmet a 'posztmodernizmus', mióta a hetvenes években két ellentétes politikai tábor a kifejezést elbitorolta: egyik oldalon az újkonzervativok, akik egy 'ellenséges kultúra' állitólagos szubverzív tartalmaitól kivánnak megszabadulni az újonnan életre keltett tradíciók javára; a másik oldalon pedig azok a radikális növekedéskritikusok, akik számára az Új Építészet a modernizáció által elöidézett pusztítás szimbólumává vált."

Egy új korszak csupán akkor képes artikulálni önmagát, mely legitimációs bázisa is egyben, ha újat - új tereket, időket, új társadalmi szubjektumokat és új kulturális objektivációkat termel ki magából - mutat fel. Ez az újdonság csak akkor különböztethető meg a már ismerttől, ha az eredetiség- és szingularitástermelés letéteményesei (jelen esetben a posztmodern korszak politikai és szellemi elitje) az előző korral szemben határozzák meg önmagukat. Míg a reneszánsz el kívánt határolódni a középkortól, melyet „sötétként” denunciált, addig a barokk a reneszánsztól próbált megszabadulni, a romantika a felvilágosodástól, stb. Nem véletlen, hogy a „posztmodern döntően antimodernként viselkedik." "5 Míg az újkonzervatívok haszonélvezői a posztmodern kornak, hiszen ők az új uralkodó osztály, addig az ifjú- és ókonzervatívok a

\footnotetext{
2 Theodor W. Adorno: Esztétikai elmélet. Fordította: Teller Katalin. Kiadatlan kézirat, 22.

${ }^{3}$ Ernst Bloch: Az utópia szelleme. A második (1923-as) fogalmazvány átdolgozott kiadása. Fordította: Mesterházi Miklós. Budapest: Gond-Cura Alapítvány 2007, 399-400.

4 Jürgen Habermas: „Moderne und postmoderne Architektur”. In: Die Neue Unübersichtlichkeit. Kleine Politische Schriften V. Frankfurt am Main: Suhrkamp 1985, 12.

${ }^{5}$ W. Pehnt Die Postmoderne als Lunapark (in: Frankfurter Allgemeine Zeitung, 1980. október 18., 17.) c. cikkéből idéz Habermas: „Egy befejezetlen projektum - a modern kor”, 151.
} 
későmodernitástól élesen elhatárolódva megtagadnak vele bármifajta azonosulást. ${ }^{6}$ A radikális imaginárius ${ }^{7}$ szemszögéből nézve a posztmodern skizofrén alámerülés ${ }^{8}$ a modernitás tudattalanjába. Felemás beköszönte, mely még évtizedek múltán is artikulál(hat)atlannak - ami abból a belátásból fakad, hogy amit nem lehet kifejezésre juttatni, annak a legitimációs bázisát, a létjogosultságát sem lehet megteremteni - vagy csak korlátozottan artikulálhatónak bizonyult, azon a feloldhatatlan ellentmondáson alapult, hogy, noha pozícióját a modernitással szemben vette fel, mégis, annak örökségéből táplálkozott. Ezt a „furcsa feltámadást” már maguk a korszakhatárt jelölő „,posztisztikus"9 fogalmak is adekvát módon érzékeltetik: „posztindusztriális társadalom” (gazdaság), „poszstrukturalizmus”, „posztempirizmus”, „posztracionalizmus” (szellem-, társadalom- és természettudományok), „posztfakticitás”/post-truth (episztemológia), posztpolitika (politika), ,posztmaterialitás” (szociológia) stb. A történelmet a historizmus paradigmájának mércéjével mérve talán már nem is írják, hiszen „véget ért” ${ }^{10}$ (posthistoire). Az

\footnotetext{
${ }^{6}$ Habermas így jellemzi a konzervatív tömb három frakcióját: „Az ifjúkonzervatívok magukévá teszik az esztétikai modernség alapvető tapasztalatát, a kogníció és a célszerü tevékenység minden korlátjától, a munka és hasznosság minden imperativusától megszabadított, decentrált szubjektivitást - s kitörnek vele a modern világból. [...] Az ókonzervatívok nemigen hagyják magukat megfertőzni a kulturális modernséggel. Gyanakodva figyelik a szubsztanciális ész felbomlását, a tudomány, erkölcs és müvészet elkülönülését, a modern világértelmezést $\mathrm{s}$ annak immár csupán procedurális racionalitását, $\mathrm{s}$ a modern kor elötti pozíciókhoz valóvisszatérést ajánlják [...]. [...] [A]z újkonzervatívok [...] üdvözlik a modern tudomány fejlödését, amennyiben az csak azért lép ki saját határai közül, hogy a technikai haladást, a tőkés növekedést és a racionális igazgatást előbbre vigye.” Jürgen Habermas: „Egy befejezetlen projektum - a modern kor”. In: Jürgen Habermas - Jean-François Lyotard - Richard Rorty: A
} posztmodern állapot. Fordította: Nyizsnyánszky Ferenc. Budapest: Századvég 1993, 175-176.

${ }^{7}$ Castoriadisnál a radikális imaginárius terminusa két további alkategóriára bomlik: 1. a társadalmi imaginárius ra és 2. a radikális imagináció ra, melyeket a következőképpen jellemez: „A radikális imaginárius csak mint társadalmi-történelmi (GesellschaftlichGeschichtliches) és mint psziché-szóma létezik. Társadalmi-történelmiként a radikális imaginárius a névtelen kollektívum nyitott áramlása; psziché-szómaként a képzetek/affektusok/törekvések áramlata. Ami a társadalmi-történelmiben tételezés, teremtés, lenni hagyás, azt eredeti értelemben társadalmi imaginárusnak vagy intézményesítő társadalomnak nevezzük. A társadalmi imaginárius, avagy az intézményesítő társadalom a társadalom imaginárius jelentéseinek és az intézményesség tételezéséből/teremtéséből áll, illetve ezek által létezik; az intézmény ezen jelentések „megjelenítése” és ezek a jelentések intézményesülnek. A radikális imagináció az alakzatok tételezéséből/teremtéséből áll és ezek által létezik mint a jel megjelenítése és a jel mint állandóan alakított és elképzelt jel. A társadalom intézményessége az intézményesítő társadalom által az eleve adott (Gegebenes) eredeti, természetes rétegére támaszkodik és a már intézményesítettel mindig - egy sohasem kifürkészhető eredetpontig - a felvétel/mássá keletkeztetés (Anderswerdenlassens) kapcsolatában áll." Castoriadis: Gesellschaft als imaginäre Institution, 603-604.

${ }^{8}$ Fredric Jameson találó megfogalmazása. Vö. Fredric Jameson: „Térbeli megfigyelők a világrendszerben”. In: A posztmodern, avagy a kései kapitalizmus kulturális logikája. Fordította: Dudik Annamária Éva. Budapest: Noran 2010, 130.

${ }^{9}$ Wellmer a posztmodern állapotot egyértelmüen az ész, nagyobb távlatokban pedig a felvilágosodás(ba vetett hit) végérvényes diszkreditálódásához, halálához köti. Ennek a kulturális hozadékai azonban korántsem magától értetődőek, hanem, ahogy Wellmer sejteti, a dialektika paradigmáján belül szemléletfüggő - egyik oldalon beszélhetünk „,demitologizált marxizmusról”, míg a másik oldalon az új, harmadik utas baloldal (Giddens, Blair, Labour) és a baloldali elméletek és mozgalmiság iránti igény feltámadásáról, sőt, fokozódásáról, stb. „A ‘posztmodern' a 'posztisztikus’ fogalmak és gondolkodási módok ama hálójába tartozik - 'posztindusztriális társadalom', 'posztstrukturalizmus', 'posztempirizmus', 'posztracionalizmus' - amely fogalmakban, úgy tünik, egy olyan korszakváltás tudata próbál artikulálódni, melynek kontúrjai még nem világosak, elmosódottak és kétértelmüek, de amelynek központi tapasztalata, az ész haláláé, egy történelmi program definitív végére tünnek utalni: a modernség, az európai felvilágosodás programjának, vagy úgy is mondhatnánk, hogy a görög-nyugati civilizáció programjának a végére. A ‘posztisztikus' fogalmak és gondolkodásmódok hálója persze többértelmü ábrákra hasonlít: egyszerre lehet felfedezni benne a radikalizált modernség, egy a maga dolgaiban is felvilágosult felvilágosodás és egy posztracionalisztikus észfogalom kontúrjait. Ebből a szemszögből nézve a posztmodernizmus demitologizált marxizmusnak, az esztétikai avantgardizmus folytatásának vagy a nyelvkritika radikalizálásának tűnik.” Albrecht Wellmer: „A modern és posztmodern dialektikája. Az észkritika Adorno után”. In: A modern és posztmodern dialektikája. Az észkritika Adorno után. Fordította: Weiss János. Budapest: Gond - Cura Alapítvány 2008, 63.

${ }^{10}$ Fukuyama a Történelem vége koncepciójával a vulgáris olvasatokkal ellentétben nem azt állítja, hogy az események egymásba fonódó láncolataként felfogott történelem egy ponton mintegy megszünik létezni, hanem sokkal inkább azt, hogy az általa feltételezett, világszintü hegemóniára szert tevő liberalizmus alapelvei mind a gazdasági formációként vett szabadversenyes 
Kaleidoscope

etimológiából kiolvasható logikus felismerés azt implikálja, hogy valami (jelentös) után vagyunk, de azt még nem tudjuk, hogy most mi van, még kevésbé azt, hogy ezután mi fog következni. Feltételezhetjük, hogy a „szellem diadala” (totalitariánus ideológiák, társadalmi racionalizáció, árutermelő ipar, strukturalizmus, soha nem látott technikai fejlettség stb.) és a képzelőerő páratlan léptékü felszabadítása (avantgárdok) után a szellem mintegy takaréklángra kapcsolt, a szellemi kultúra szünetel. Ebből az következik, hogy a posztmodern korszak egyik legfőbb sajátossága, hogy nincsen szüksége - vagy a racionalizációs rendszerek represszív-totalitariánus konglomerátumokba való átcsapásával radikális szkepszis jellemzi - egy olyan fogalmi mátrixra, melynek világleképező struktúrája dialektikus ellenfogalmakból tevődik össze. Ennek az új artikulál(hat)atlanságnak maga a korszak névadó fogalma, a „posztmodern” szimptomatikusan feltünteti, hogy nem egy radikális cezúra következett be az 1970-es évektől kezdődően, hanem egy imént még itt volt, mára már letünt korszaknak a - némiképp módosult - meghosszabbításába (poszt-modern) léptünk. A helyzet problematikusságát tovább fokozza a totális ideológiák gyanúja (totaler Ideologieverdacht), miszerint minden iskolateremtő teoretikus szisztéma politizálódik, majd előbb vagy utóbb szélsőségesen elnyomó önkényuralmi rendszerré totalizálódik. A posztmodern nem csupán korszakjelölő határfogalom, hanem elsősorban a kései kapitalizmus szociokulturális logikája. ${ }^{11}$ Ez azt jelenti, hogy a posztmodern esetében egy olyan felépítmény-jelenségről beszélhetünk, mely a kultúrát olyan mértékben áthatja, hogy impregnálja a közgondolkodást és általában véve a korszellemet, hogy mindez - visszahatva - befolyásolja a gazdasági-politikai folyamatokat is - az elitek által pályára állított kulturális logika ennélfogva ontologizálódik. A posztmodern korszak legföbb fundamentálontológiai sajátosságának tekinthetö, hogy az élet- és gondolatvilág permanens le- és elhatárolásai által határozza meg önmagát - vagyis a különbséggondolattal tesz szert önazonosságra (identitás differencia által).

Eszme- és gazdaságtörténeti értelemben a posztmodern az utolsó nagy elbeszélés- és racionalitásrendszerek, nevezetesen a (neo)marxizmus és a strukturalizmus természeti katasztrófához fogható, belülről bekövetkező hirtelen felbomlásával, illetve letüntével és az ezzel egyidejü neoliberalizmus/neopozitivizmus felemelkedésével került domináns, végleg győztes hatalmi pozícióba. ${ }^{12}$ Ha a marxizmus „bebiztosított dogmatizmus” (Karl R. Popper), ${ }^{13}$ úgy a „poszt ideologikus” posztmodern

kapitalizmus (bázis), mind a politikai-társadalmi berendezkedésként értelmezett liberális demokrácia (szuperstruktúra) formájában olyannyira sikeresen határozzák meg a világ társadalmainak müködési mechanizmusait, hogy azok, ekképp Fukuyama, az immár voltnak mondható Szovjetunió és a „keleti blokk” államszocializmusaihoz/államkapitalizmusaihoz képest belső ellentmondásoktól mentesen képesek kielégíteni a társadalmi szükségleteket, ezáltal a történelem mozgatórugójaként tételezett harc az elismerésért (Kampf um Anerkennung) okafogyottá válik, hiszen nincs miért küzdeni abban a társadalomban, ahol elméletileg minden a társadalom tagjainak rendelkezésére áll. Fukuyamának a történelem végéről szóló tézise - melynek fogalma már Hegel (liberális polgári társadalom) és Marx (a kommunizmus eljövetele) életművéből is kiolvasható - tehát kettős: egyrészt azt állítja, hogy a posztmodern állapotban nem csak azért beszélhetünk a Történelem végéröl, mert nincs többé egy egységes, „egyetlen, összefüggő és következetes fejlődési folyamatként értelmezett történelem (lyotard-i megfogalmazásával élve a posztmodern állapotot a ,nagy elbeszélésekkel, metanarratívákkal szembeni bizalmatlanság jellemzi), hanem mert a liberális demokráciában koncipiált ,alapvető elvek és intézmények nem fejlődnek tovább, mivel a valóban nagy kérdések már mind rendeződtek." Francis Fukuyama: A történelem vége és az utolsó ember. Fordította: Somogyi Pál László. Budapest: Európa 1994, 2-3.

11 Így határozza meg első lépésben Fredric Jameson a posztmodern fogalmát azonos című könyvében.

${ }^{12}$ Kiss Endre: „Kísérlet a posztmodern empíriáról”. In: Globalizáció és/vagy posztmodern. (Tanulmányok a jelen elméletéről). Főiskolai jegyzet. Budapest/Székesfehérvár: Kodolányi János Főiskola 2003, 198.

13 Popper a marxizmust „bebiztosított dogmatizmusként” dezavuálja: „Hogy elbánjon vele [a marxizmussal], kiagyalta a bebiztosított cáfolat módszerét. Elmondja, amit a marxizmus gondol, és megmutatja, mennyire rossz is az. És ha egy marxista azt veti ellene, hogy „Hiszen ez nem az, amit mi marxisták mondunk!”, akkor így válaszol: „Ez az, amire a marxizmus gondol.” Hogyan válaszolhat valaki az ilyen cáfolatra? Mint dr. Popper mondja A nyílt társadalom és ellenfelei címü könyve második kiadásához írt előszavában: „Kritikám megsemmisítő volt.” Maurice Cornforth: A nyílt filozófia és a nyilt társadalom. Hogyan cáfolta meg dr. Karl Popper a marxizmust?. Fordította: Sós Vilmos. Budapest: Gondolat 1975, 31. 
Kaleidoscope

állapot a „bebiztosított legitimáció” korszakának tekinthetö. Misszionárius programja szerint minden átfogó, társadalomszervezö és -átalakitó potenciállal rendelkezö politikafilozófiai eszmerendszert, ideológiát a „totaliarianizmus” szerfelett a felületes indulatokra, érzelmekre apelláló, önnön partikuláris morálprédikációs aggregátumát univerzáló gyanújával értelmez át, ezért nem marad más választása, minthogy ezt az időszakot „,posztideologikusnak” minösitse, amikor is a társadalmat, történelmet és az általában vett világot mesternarrativákként leíró ideológiák korát egyszer és mindenkorra önigazoló módon lezárultnak nyilvánítja. Hogy létezik posztideologikus világnézet és egy ehhez kapcsolódó világnézet, feloldhatatlan önellentmondásokba bonyolódó állítás: nincsenek és nem is létezhetnek ártatlan világnézetek, elsősorban filozófiai értelemben nem, mert „az ész mellett vagy az ész ellen való állásfoglalás eldönti egyúttal egy filozófiának mint filozófiának lényegét, a társadalmi fejlődésben betöltött szerepét. Már csak azért is, mert maga az ész nem lehet a társadalmi fejlődés felett lebegő, pártatlanul semleges valami, hanem mindenkor egy társadalmi helyzet, egy fejlödési irány konkrét ésszerüségét (vagy ésszerütlenségét) tükrözi vissza, fogalmazza meg, s ezzel ezt a fejlődési irányt előbbre viszi vagy gátolja."14 A posztmodern gondolkodás annyiban tekinthető a posztideologikusság ideológiájának, hogy nemhogy nem hisz már semmiféle eszmében, a saját magáén kívül, hanem minden eddiginél radikálisabban relativizálja a filozófiát, minden eddiginél gyökeresebben hajtja túl a dekonstrukciót. ${ }^{15}$ Ahol ilyen mértékű a gondolkodás és az életvilág destabilizálódása, ott a posztmodern empíria fogalmának esetében is csak egy korlátozott, erősen fragmentált valóság- és társadalomérzékelésről beszélhetünk, ami a fenomenológiai-ontológiai destrukciót túlélve, a reziduális mozzanatokból nő ki. ${ }^{16}$ A jelent még nem lehet teljességgel megragadni a múlt maradványaiból és egységes, holisztikus rendszerbe rendezni. Pontosan ezt az (átmeneti) állapotot fémjelzi az „Új Áttekinthetetlenség” elnevezése is.

Habermas az újonnan beköszönő korszakot az Új Áttekinthetetlenség (Neue Unübersichtlichkeit) fogalmával írja le: „Ezzel az „utó-” előtaggal („nach”) kívánják a szereplők elhatárolni magukat; még nem képesek új nevet adni a jelennek, mert még nem vagyunk a jövő felismerhető problémáira adott válaszok birtokában. Az olyan formulák, mint a „későfelvilágosodás” vagy a ,posthistoire”, ugyanennek a szolgálatnak tesznek eleget. Az elhamarkodott búcsúztatás ilyetén gesztusai az átmenet periódusába illeszkednek." ${ }^{17}$ A társadalmi rend attribútuma lehet az áttekinthetetlenség. A kérdés az, hogy ezt az (átmeneti) felfordulást kívánatosnak vagy elutasítandónak tartjuk-e. Nehezen elképzelhető, hogy egy politikai érdekcsoport kívánatosnak tartana egy akárcsak ideiglenes áttekinthetetlenséget, hiszen ez irányítóés ellenőrző funkcióinak megrendülését, végső soron hatalmának felbomlását jelentené be. Egy kordiagnosztikus teoretikus számára jelenthet előnyt egy efféle rendetlenség, amennyiben képes

A konkurens elméletek ellen fellépő, a totalitarizmus látens gyanújával élő újkonzervatívok mindenre kiterjesztett ideológiaellenességük mögött valójában annak a szándéka áll, hogy saját vezéreszméjüket mint ideológiát vonják ki az ideologikus ellenőrzés alól, mindezzel megszilárdítva saját hatalmi pozícióikat. Mivel a posztmodern korszakban az újkonzervativizmus politikai programjához a neoliberális társadalmi-gazdasági átalakítások politikai agendája társul, ezáltal világméretü hegemóniára tesz szert. Ami globálisan, planetárisan általános érvényü, azt könnyüszerrel lehet „,adottnak”, „természetesnek”, ezáltal „nem megkérdőjelezhetőnek” tételezni. Ezen megfontolások alapján az újkonzervatívok politikai stratégiáját megalapozottnak vélem „,bebiztosított legitimációként” jellemezni.

${ }^{14}$ Lukács György: Az ész trónfosztása. Az irracionalista filozófia kritikája. Budapest: Akadémiai Kiadó $1974,4$.

${ }^{15}$ Kiss Endre: „A posztmodern gondolkodás rekonstrukciója”. In: Globalizáció és/vagy posztmodern. (Tanulmányok a jelen elméletéről). Főiskolai jegyzet. Budapest/Székesfehérvár: Kodolányi János Főiskola 2003, 76.

16 A következőket állítja Kiss a posztmodern empíriáról: „Mivel a posztmodern gondolkodás alaptípusai (Foucault-ra és Derridára gondolunk) kritikusan megnehezítik, sőt egyenesen lehetetlenné is teszik az empíriához való közvetlen közeledést, a posztmodern empirizmus első csírái szükségszerüen (mondhatnánk kénytelenséget is) a reziduális mozzanatokból nőnek ki. Reziduálisnak nevezzük ebben az összefüggésben az olyan kiindulásokat, amelyek az empíria klasszikus destrukcióinak véghezvitele után is valamilyen mértékben megmaradnak, elsősorban azért (maradnak meg), mert egybeesnek az empíria destrukciójának általános szempontjával.” Kiss: „Kísérlet a posztmodern empíriáról”, 201.

17 Jürgen Habermas: Die Neue Unübersichtlichkeit. Kleine Politische Schriften V. Frankfurt am Main: Suhrkamp $1985,11$. 
Kaleidoscope

szisztematizálni azt, megteremtve ezzel önnön legitimációs bázisát is. Az áttekinthetetlenség diagnózisával ugyanakkor - még ha csak futólagosan is - új társadalmi ontológiát alapozunk meg. Performatíve kijelentjük, ami egyben egyfajta önbeteljesítő jóslatként is hat, hogy az áttekinthetetlenség létezik és egyelöre nem vagyunk képesek ennek felszámolására, noha a „lét utópiákat szül, ezek pedig szétfeszítik a létet, továbbterelik egy következő lét felé."18 A konkrétumok relativizálódásával és a vezéreszmék dekonstrukciójával a jelen társadalmának önmagából merítve kell önmagát kell megalapoznia. „Elhomályosultak a múlt példaértékü eseményei (exemplarische Vergangenheiten), melyekhez a jelen gond nélkül igazodhatna. A modernség már nem képes orientáló mércéket kölcsönözni más korok példaképeitől; kizárólag önmagára hagyatkozhat, normativitását önmagából kell merítenie. Ettől kezdve az autentikus múlt az a hely, ahol a hagyomány folytatása és az innováció egymásba fonódik." ${ }^{19}$ A dolgok néven nevezésére és az elementáris temporális distinkciók (régi - új) ${ }^{20}$ megtételére való képtelenség azt az impotenciát is elöfeltételezi, hogy feltegyük a korszak szempontjából nézve döntő jelentőségű kérdéseket. Vagyis Baudrillard rendkívül találó metaforájával élve, nem tudjuk, hogy mit tegyünk a modernitás mint „orgia” után. ${ }^{21}$

Kérdés azonban, hogy a dolgok állása valóban így fest-e. Habermas könyve 1985-ben jelent meg, ami semmi esetre sem tekinthető a posztmodern korai fázisának, inkább a korszak betetőzésének. Lényeges valamelyest rendet tenni abban a fogalmi zürzavarban, melynek esetleges fenntartásában maga a posztmodern - még ha a korszakkal szemben kritikus is - értelmiség teoretikusai és politikai stratégái különösképpen érdekeltek. Mintha a posztmodern beköszöntével meghonosodott fogalmak, mellyel társadalmi valóságunkat leírni kívánjuk, homályos meghatározottsága vagy éppen jóformán tetszőlegesen hajlékony újradefiniálhatósága és nem utolsó sorban immateriális jellege - még ha csak látszólagosan is maga is a korszakot jelölő posztmodernből mint a terminológiai burjánzás fogalmi főhadiszállásából táplálkozna. Minél erősebben hiposztazáljuk a posztmodern fogalmát, annál inkább fennáll a veszélye annak, hogy a terminus a kitágított fogalomalkotás révén kiüresedik. Ha állításunk annyit, hogy a posztmodern egy, a modernitást felváltó gyüjtőfogalom, felmerül a kérdés, hogy mely szempontok szerint lehet a jelenséget a legkielégítőbben megvizsgálni. A posztmodern filozófiai megközelítése szükséges, de

\footnotetext{
${ }^{18}$ Mannheim Károly: Ideológia és utópia. Fordította: Mezei I. György. Budapest: Atlantisz 1996, $228-229$.

${ }^{19}$ Jürgen Habermas: „A jóléti állam válsága és az utópikus energiák kimerülése”. In: Válogatott tanulmányok. Fordította: Adamik Lajos, Bendl Júlia, Felkai Gábor. Budapest: Atlantisz 1994, 283.

20 A modern kifejezésének első használatakor is, funkcióját tekintve, elhatárolódásra (azonosság- és különbségelméleti alapállítások megtételére) szolgált: „A ‘modern’ kifejezést az 5. század vége felé használták első ízben, azzal a céllal, hogy az éppen hivatalossá vált keresztény jelenkort elhatárolják a pogány-római múlttól. A 'modernitás' [Modernität] változó tartalmakkal fejezi ki újra és újra egy-egy olyan korszak tudatát, amely kapcsolatba hozza magát az antikvitás múltjával, azzal a céllal, hogy önmagát a régiről az újra való átmenet eredményeként értelmezze.” Jürgen Habermas: „Egy befejezetlen projektum - a modern kor". In: Jürgen Habermas - Jean-François Lyotard - Richard Rorty: A posztmodern állapot. Fordította: Nyizsnyánszky Ferenc. Budapest: Századvég 1993, 153. Régi és új különbségéről - gondoljuk ide ennek korszakmeghatározó potenciálját, vagyis relevanciáját is - a következő fogalomtörténeti adalékokkal szolgál Márkus: „A 'modernus', a 'modern' egyszerüen azt jelenti, ami most van, ami jelenkori, szemben azzal, ami ‘antiquus’, ami elmúlt, tovatünt.” Márkus György: „A kultúra társadalma - a kulturális modernitás konstitúciója". In: Kultúra, tudomány, társadalom. A kultúra modern eszméje. Fordította: Lánczi András. Budapest: Atlantisz 2017, 31.

${ }^{21}$ Baudrillard sokakat megelőzve talán elsőként észlelte, hogy az új kor nem valami újnak a beköszöntével ekvivalens, sokkal inkább az elmúlt modernitás (szexuális-eksztatikus) „orgiája” utáni kifulladás élményéhez hasonlítható. „Az orgia a modernitás kirobbantásának, a minden téren való felszabadulásnak a pillanata. Politikai felszabadulás, szexuális felszabadulás, a termelőerők felszabadulása, a pusztító erők felszabadulása, a nő felszabadulása, a gyermeké, a tudattalan ösztönöké, a müvészeté. [...] Ez a megvalósult utópia állapota, minden megvalósult utópiáé, amelyben furcsa módon úgy kell tovább élni, mintha nem valósultak volna meg. De minthogy megvalósultak, és minthogy már nem reménykedhetünk abban, hogy megvalósíthatjuk öket, nem marad más hátra, mint a valóságon túli megvalósításuk véget nem érő szimulációval.” Jean Baudrillard: „Az orgia után”. In: A Rossz transzparenciája. Esszé a szélsőséges jelenségekröl. Fordította: Klimó Ágnes. Budapest: Balassi Kiadó - BAE Tartóshullám Intermédia 1997, 10.
} 
Kaleidoscope

nem elégséges kritikai analízisét nyújtja a posztmodern korszak életvilágának. Az irodalmi posztmodernből meglehetősen kevés posztmodern formai struktúra és esztétikai minőség, szövegalkotási stratégia tünik a posztmodernizmus mindenkori jelenére alkalmazhatónak, és akkor is csak erőteljes absztrakciókkal követhetjük nyomon. ${ }^{22}$ A posztmodern szociológia (és a többi társadalomtudomány) számos esetben adekvát módon képes feltérképezni a korproblémákat és társadalmi jelenségeket, bár itt is érvényesül a posztisztikus fogalmak többségében kimutatható „elszipkázott materialitás” - melyek azt az ideologikus látszatot keltik, hogy napjainkra okafogyottá vált társadalomformáló eszmékröl, anyagi viszonyokról és materiális érdekeltségekről beszélni. Míg az előbbit tekinthetjük a posztmodern állapot szociológiájának rendszerkritikus, problémaérzékeny irányzatának, ${ }^{23}$ a másik ehelyett inkább rendszerlegitimáló társadalomelméleti leírásokra törekszik. ${ }^{2425}$ Habermas '85-ös társadalomfilozófiai kötete méltán tartozik az utóbbi kategóriába. A fennálló rend kiváltotta politikai, társadalmi és gazdasági problémáinak megoldása esetében legalább annyira fontos kiemelni, hogy hogyan észleljük ezeket a problémákat, mint azok konkrét megoldási javaslatok kidolgozásán fáradozni. A problémaészlelés és annak fogalmi leképezése virtuálisan magában foglalja a megoldás lehetőségfeltételeit is. Megfordítva: egy társadalmi, gazdasági vagy politikai válság magával vonja a korábban használt fogalomkészletünk érvényességének megrendülését is, hiszen az új jelenségekre és problémakomplexumokra többé már nem alkalmazhatóak, illetve még nem vagyunk képesek fogalmilag artikulálni a változásokat. Ekkor pedig nem is tudjuk pontosan, milyen irányban kell megváltoztatni az újonnan létrejöttet. Pontosan erre mutat rá Jameson, hogy - a kevés pozitív ellenpéldát leszámítva - a posztmodern gondolkodás erőteljesebben formálja a gondolkodásunkat, semhogy abból teljességgel képesek lehetnénk kireflektálni magunkat, ami márpedig egy rendszerkritikai kordiagnózis elöfeltétele lenne.

„A lényeg az, hogy annyira benne vagyunk a posztmodernizmus kultúrájában, hogy annak könnyed elutasítása legalább akkora képtelenség, mint amennyire felszínes ünneplése önelégült és hibás. Azt

\footnotetext{
${ }^{22}$ A posztmodern irodalom legfőbb stiláris jellegzetességei közé tartozik a meghatározatlanság, a fragmentáltság, a kánon felbomlása, az olyannyira erőteljes müfajkeveredés, hogy a szövegstílus már a formális besorolhatatlansághoz közelít. Ha a posztmodern életvilágra kívánjuk alkalmazni ezeket az irodalmi karakterisztikumokat, akkor a meghatározatlanság egyaránt vonatkoztatható a bizonytalan életviszonyokra, és az elöre rögzíthető egyéni életpályák kimenetelének előrejelezhetetlenségére; a kapitalizmus önfenntartása érdekében az egyes lét- és termelési szférák leválasztásain (detachment) alapul, amit a rendszerlogika még a strukturális egyenlőtlenségekkel is súlyosbít. Nem csak a társadalmi valóság tekinthető széttöredezettnek, hanem maga a posztmodern szubjektum is, amit a rendszer magából kitermel. A későmodernitás ideáltipikus szubjektuma egy lényegéből fakadóan fogalom- és emlékezetellenes kultúrában nem képes érzelmeit és gondolatait egy önálló egységgé szervezni ahhoz, hogy meg tudja határozni saját identitáspozícióiját, a társadalmi viszonyok törésvonalaiban betöltött mindenkori helyét, stb. A kánon felbomlását érthetjük a nagy narratívák végeként is - amikor a jelenből már nem építhető narratíva, hiszen a múltból ismert nagy elbeszélőrendszerek (pozitivizmus, strukturalizmus, marxizmus stb.) idejét múltnak tűnnek a jelen perspektívájából, és számos esetben nem adnak kielégítő válaszokat a gyökeres szerkezetváltozásokon átment posztmodern állapotban uralkodó társadalmi antagonizmusokra és belső ellentmondásokra. A posztmodern kultúrában lépten-nyomon tetten érhető müfaji keveredés tudati kuszaságot is eredményez, ami határozottan egyenértéküsíthető a klasszikus marxi ideológia „hamis tudatként” történő meghatározásával.

${ }^{23}$ Ld. például Zygmunt Bauman, Scott Lash, David Harvey, Bourdieu, Latour rendszerkritikai munkásságát.

${ }^{24}$ Ld. például Parsons, Luhmann, Giddens, az evolucionista rendszerelmélet (Humberto Maturana, Francisco Varela) képviselöit, a modernizációs iskola és a később a rendszerváltás után a kelet-európai térségre alkalmazott „modernizációs paradigma” képviselőit, az ún. tranzitológusokat és végül, de nem utolsó sorban, az Európai Unió müködésmódját legitimáló Habermas kései korszakát .

${ }^{25}$ A posztmodern jellegzetes represszív idealizmusára, amely a materialitás meghaladásának látszatát kelti, ami jelen esetben a II. világháború után kiépülő nehéz- és könnyüipar harmadik világba történő kiszervezésével egyenlö, vall a korszak uralkodó szociológiai elméleteiben tetten érhető kvázi-immateriális-idealisztikus fogalomhasználat: a „posztindusztriális” jelzővel a szociológusok azt kívánják hangsúlyozni, hogy az ipari kapitalizmus egyszerüen továbbfejlödött, hogy az új szolgáltatási szektorok a közvetlenül termelői szektorok költségére terjeszkedtek ki. Vö. Habermas: „Moderne und postmoderne Architektur”,
} 12. 
Kaleidoscope

gondolhatnánk, hogy ma a posztmodernizmus ideológiai megítélése szükségszerủen együtt jár azzal, hogy nemcsak a kérdéses müalkotásokról, de magunkról is ítéletet mondunk; emellett egy egész történelmi korszakot, amilyen a miénk is, globális erkölcsi ítéletekkel vagy azok valamelyest elkorcsosult megfelelőjével, a konyhapszichológiai diagnózisokkal nem lehet kielégítően megragadni." 26

Erősen kétséges tehát, hogy a posztmodernben végbemenő kulturális termelés modelljéül szolgálhatna a klasszikus marxista felépítmény-fogalom, ugyanis a kulturális szféra és a materiális termelési viszonyok olyannyira áthatják egymást, hogy fogalmilag megkülönböztethetőek, müködési mechanizmusaikban azonban szétválaszthatatlanok egymástól. A posztmodern állapotban legalább annyira beszélhetünk a reprezentáció materializálódásáról, ${ }^{27}$ mint amennyire érvényes, hogy a kultúripar szakadatlan képtermelésének anyagi együtthatók a biztosítékai. A posztmodern esetében különösképp jelentőséget nyer az az állítás, hogy egy konstrukció attól még, hogy elmeszülemény, ember által létrehozott tudattartalom, ugyanúgy a társadalmi ontológia részévé válhat, sőt, egyre nagyobb felhajtóerővel bírva elkezdheti szervezni, végül pedig meghatározni azt. ${ }^{28}$ Baudrillard még ennél is tovább megy, amikor a szimulákrum valósághoz igazításáról beszél. ${ }^{29}$ Eszerint a posztmodern egy hiperreális konstrukció, ami Jameson meghatározását követve a kései kapitalizmus kulturális logikájaként értelmezhető, mely materiális bázisát az 1970-es évektől felívelő neoliberalizmusból és az azt infrastruktúrával ellátó globalizációból nyeri. Ezért írja Jameson, „ildomosabbnak tünik az új kulturális termelést a kultúra általános átalakulásának munkahipotézisén belül és a késő kapitalizmus mint rendszer társadalmi átstruktúrálódásával együtt elemezni." 30

Habermas jelen könyvében nagyon pontosan felismerte, hogy a posztmodern gondolkodás, már amennyiben nem egy posztmarxista-rendszerkritikai kiindulópontokról beszélünk, alapvetően restauratív stratégiára épül: már a fogalomból is kiolvasható, hogy programmatikusan el kíván határolódni a 19-20. századi modernitástól, melynek egyébként kulturális, politikai és teoretikus értelemben is örököse és nem utolsó sorban haszonélvezője. Ideologikus átértelmezésekből meríti önlegitimációját a kultúrában, a politikában és a gazdaságban: kulturális értelemben a posztmodern búcsút mond a képzelet felszabadításának, melyet a már meglévő stílusirányzatok, formanyelvek nem ritkán egymással teljességgel inkommenzurábilis amalgámmá elegyítésével és üzemszerü sokszorosításával helyettesít (elnyomás mint felszabaditás). Noha nem tudni pontosan, mi történik a színfalak mögött, a politikusoknak eleget kell tenniük a demokratikusság látszatának. Ha a kormányzás nem is transzparens, óriási szavazóbázisra lehet szert tenni egy jól időzített szimbolikus politikai gesztussal. Ha egy politikus untig ismert szólamokat hangoztat vagy leplezetlenül cinikus, akkor is a legfontosabb, hogy mindezt határozott kiállással mondja. A közösségi médiában mindenki elmondhatja a véleményét, ami azt az érzést kelti, mintha egy komment egyben politikai tett volna.

\footnotetext{
${ }^{26}$ Jameson: „A posztmodern elméletei”, 80.

${ }^{27}$ Ebben az összefüggésben Debord a következőket írja: „A spektákulum nem fogható fel a tömeges képterjesztési technológia kit ermelte látványvilággal való visszaélésként. Sokkal inkább egyfajta Weltanschanung, amely megvalósult, anyagszerüvé vált. A spektákulum objektiválódott világlátás." Guy Debord: A spektákulum társadalma. Fordította: Erhardt Miklós. Budapest: Balassi Kiadó - BAE Tartóshullám 1992, 3.

${ }^{28}$ Elmegy a lényeg mellett az a felszínes kritikai állítás, miszerint ez és ez csak konstrukció. A társadalmi intézmények és maga a társadalom absztrakt ideája is konstrukció, mégis valós entitásokról van szó.

${ }^{29}$ Baudrillard a következőket írja ebben az összefüggésben: „Az absztrakció ma már nem hasonlatos térképhez, képmáshoz, tükörhöz vagy fogalomhoz. A szimuláció ma már nem területre, referenciális létezőre, szubsztanciára irányul, hanem egy eredet és realitás nélküli reálisnak a modelleken keresztül történő generációja. Hiperreális. A térkép előbbre való a területnél $-e z$ a szimulákrum elsőbbsége - ő hozza létre a területet, s ha újraírnánk a mesét, ma a terület foszlányai porladnának szét lassan a térkép felszínén. Nem a térkép a valóságos, hanem az, aminek nyomai itt-ott láthatók még abban a sivatagban, ami már nem a Birodalomhoz tartozik, hanem hozzánk. Maga a valóság sivataga.” Jean Baudrillard: „A szimulákrum elsőbbsége”. In (szerk.: Kis Attila Atilla, Kovács Sándor, Odorics Ferenc): Testes könyv I. Fordította: Gángó Gábor. Szeged: JATE - Ictus $1992,161$.

${ }^{30}$ Jameson: I.m., 80.
} 
Kaleidoscope

Minél nagyobb eme passzív ellenállás mértéke, annál inkább csökken elnyomott tömegek politikai mobilizálódásának eshetősége (társadalmi atomizálódás mint tömegdemokrácia).

Az avantgárd impulzusokat saját leleményességének tünteti fel, noha csak annyiban van rájuk szüksége, hogy azt a kultúripar és a politikai érdekszférák represszív toleranciájának szolgálatába állítsa. A gazdasági értelemben vett posztkoloniális állapot valójában a volt és új gyarmati függőségek fenntartása/megteremtése, az imperialista expanzió és geopolitikai érdekeltségek valódi feloldása, és egy posztrasszista-posztetnicista állapot megteremtése nélkül. A nyugati típusú flexibilis munkavégzés valójában eufemisztikus újrafogalmazása a munkafeltételek teljes prekarizálódásának. Az emberi és nememberi energiák és erőforrások végeérhetetlen kiszipolyozásán alapuló szabadversenyes kapitalizmust továbbra is egy „láthatatlan kéz” igazgatja az üzleti ideológia represszív idealizmusa jóvoltából (,,poszttotalitariánus” korszak mint a gazdaságpolitikai függőségek új típusú rendszere). A posztmodernben a szimulált valóság válik új realitássá, ami pedig túlmutat, vagy egyenesen ellentmond a rendszer logikájának, azt kíméletlenül visszavágják.

Jameson pontosan azt tartja Habermas nagy érdemének, hogy éleslátóan felismerte a posztmodern stratégikus gondolkodás politikailag reakciós-restauratív intencióit, amik nem csak a modernitás képzeletet felszabadító kultúrájával kívánnak egyszer és mindenkorra leszámolni, hanem annak nagy materiális igazságosságot és politikai egyenlőséget megvalósítani szándékozó projektumaival is. ${ }^{31}$ Habermas nagyívű és mélyreható tanulmányában dióhéjban vázolja fel a nyugati utópikus hagyomány legfontosabb alakjait és vezérgondolatait, részint rekapitulálva Koselleck azon téziseit, melyeket az Elmúlt jövóben, a Kritika és válságban és a Die Verzeitlichung der Utopie (Az utópia termporalizálódása) ${ }^{32}$ c. írásaiban fejtett ki a koraújkorban radikális változáson átmenő idő- és történelemszemléletről, a rendszerkritikát implikáló gazdasági és politikai válságtapasztalatról, valamint az állami dezintegráció és szociális polarizációt leküzdeni kívánó utópikus képzetek megjelenéséről. Noha a „hosszú tizenhatodik században”, amikor a kapitalizmus kialakul és megszilárdul, az utópikus gondolkodás inkább a történelmen túli igazságos társadalom lehetőségfeltételeit kísérli meg felvázolni, míg a megvalósításának módszerét nem tárja fel elöttünk, addig a 18. századi utópiák már elkezdenek érintkezésbe lépni a történelemmel. Az utópikus energiák temporalizálódásával már nem az a megválaszolandó kérdés, hogy hogyan lehetünk képesek realizálni egy földrajzilag távol eső, fiktív nem-hely ideális társadalmat, hanem az, hogy mennyire vagyunk képesek reflektálni a korszellemből kihüvelyezhető rendszerproblémákra. ${ }^{33}$ Habermas tanulmánya második felében a jóléti állam koncepcióját magát is utópikusnak tekinti, de nem a fogalom vulgáris értelmezésében, miszerint ez „csak utópia”, vagyis megvalósíthatatlan vágygondolat volt, inkább a klasszikus utópiafogalom ${ }^{34}$ értelmében, mely megvalósíthatósága ellenére már kiépítésekor magában hordozta a csak

\footnotetext{
31 „Hálával tartozunk Jürgen Habermasnak ezért a drámai irányváltásért, valamint annak újrafogalmazásáért, ami a modern mindenek feletti értékének megerősítéséből marad, valamint a posztmodern elmélet és gyakorlat megvetéséért. Habermas számára azonban a posztmodernizmus büne elsősorban annak politikai reakciós funkciójából fakad, abból a mindent átható kísérletből, hogy hiteltelenítse a modernista impulzust, amelyet Habermas maga a polgári felvilágosodással és annak még mindig univerzalizáló és utópisztikus szellemével hoz összefüggésbe.” Fredric Jameson: „A posztmodern elméletei”. In: A posztmodern, avagy a kései kapitalizmus kulturális logikája. Fordította: Dudik Annamária Éva. Budapest: Noran 2010, 76.

${ }^{32}$ Vö. Reinhart Koselleck: Elmúlt jövő. A történeti idő szemantikája. Fordította: Hidas Zoltán, Szabó Márton. Budapest: Atlantisz 2003; Uő.: Kritika és válság. Tanulmány a polgári világ patogeneziséről. Fordította: Boros Gábor: Budapest: Atlantisz 2016; Uö.: „Die Verzeitlichung der Utopie”. In: Utopieforschung. Interdisziplinäre Forschung zur neuzeitlichen Utopie. 3. kötet. Szerk.: Wilhelm Voßkamp. Stuttgart: Metzler 1982, 1-14.

${ }^{33}$ Habermas: „A jóléti állam válsága és az utópikus energiák kimerülése”, 285.

${ }^{34}$ A klasszikus utópiafogalom Richard Saage német utópiakutató történész konceptualizálása alapján két konstitutív mozzanatból épül fel: egyfelől egy politikai-gazdasági válság létrehívja az utópista kritikáját, mely rámutat a kurrens gazdasági-politikai berendezkedés tarthatatlanságára és szisztémikus antagonizmusaira. Ezt követi az utópista rendszeralternatívája, mint társadalomtervezet, ahol az egyén és a közösség boldogságát és létfeltételeit általában egy kommunista szerzetesközösséghez 
Kaleidoscope

évtizedekkel később feloldhatatlannak mutatkozó cél és módszer közt feszülő ellentmondást. A későbbiekben azon tézisét támasztja alá, hogy a II. világháború utáni nyugat-európai posztfordista társadalmakban a jóléti állam gazdasági-szociálpolitikai modellje a világháborús pusztításból való kilábalás okán alapvetően szükségszerüségből életre hívott, másfelől a szociáldemokrata pártok által felkarolt és végigvitt társadalmi projektuma kimerülő félben van, mert lassan szétfeszítik önnön belső ellentmondásai. ${ }^{35}$ „A szociális állam fejlődése zsákutcába került. Ezzel kimerültek a munkatársadalom utópiájának energiái. A legitimisták és a neokonzervatívok egy már defenzív korszellem médiumában mozgó válaszokat adnak; olyan történelmi tudatot fejeznek ki, amely meg van fosztva az utópia dimenziójától. A növekedés társadalmának disszidensei is védekezőállásba kényszerülnek. Válaszuk csak akkor lehetne alkalmas támadásra, ha nem hagynánk, hogy a szociális állam terve rögzüljön, vagy félbemaradjon, hanem a reflexió magasabb fokán újrafogalmaznánk. A szociális állam reflexívvé vált, nemcsak a kapitalista gazdaság megszelídítésére irányuló tervében a munka nem központi vonatkoztatási pont többé. Már nem lehet szó ugyanis a normává tett teljes foglalkoztatás megvédéséről. Egy ilyen tervnek nem szabadna megelégednie azzal, hogy a szavatolt minimálbér bevezetésével megtörje a bủvöletet, melyet a munkapiac bocsátott az összes munkaképes emberre, a szaporodó és egyre inkább kiszorított tartalékban lévőkre is. Bár ez a lépés forradalmi volna, mégsem volna eléggé az - akkor sem, ha az életet nem csupán a foglalkoztatási rendszer emberhez méltatlan imperatívuszaitól lehetne megóvni, hanem általában az adminisztratív gondoskodás produktivitásellenes mellékkövetkezményeitől is."36

Amit Habermas Új Áttekinthetetlenségnek nevez, az ennek a válságtendenciák által előhívott állapotnak a része, amikor még nem látni azokat a törésvonalakat, amelyek mentén átstrukturálják a fennálló berendezkedés alapszerkezetét. ${ }^{37}$ Némiképp persze kérdésre ad okot, hogy az 1985-ben napvilágot látott könyvben, amiben e jeles tanulmány központi helyet foglal el, melyet a címmel azonos kötetcím is kihangsúlyoz, felvázolt problémák ne lettek volna már évekkel korábban diagnosztizálhatók, hiszen a neoliberalizmus észak-amerikai és nyugat-európai kiépülése az 1970-es évek elejétől indult meg. Legyen szó a szociáldemokrata jóléti állam projektumának egy magasabb, reflektívebb szinten történő újradefiniálásáról vagy egy, az eddigi társadalmi modellektől radikálisan eltérő rendszeralternatívától, a munka, társadalmi igazságosság, vagyoni egyenlőség, önrendelkezés, öntevékenység stb. fogalmainak újbóli meghatározásásáért vívott küzdelmet csak akkor lehetünk képesek megnyerni, ha képesek vagyunk szétfeszíteni a kései kapitalizmus kulturális logikájaként tételezett posztmodern utópia- és történelemellenes hegemóniáját.

hasonlatos, rendkívül fegyelmezett, szigorúan újraelosztó, magántulajdont megszüntető társadalmi formációt vizionálnak, melyből a reneszánsz utópiákban egy jól kidolgozott gazdasággondolat jóformán teljességgel hiányzik még.

35 Ebben az összefüggésben Habermas a következőket írja: „Az eljogiasítással és a bürokratizálással, főleg az állami szociálpolitika produktivitás-ellenességével, a szociális szolgáltatások professzionalizálódásával és tudományossá válásával kapcsolatban lezajlott széles körü viták egy dolgot bizonyosan megvilágítottak. A szociális állam programjának megvalósítását szolgáló jogi-adminisztratív eszközök rendszere nem passzív, mondhatni tulajdonságok nélküli médium, összekapcsolódik a tények szétaprózásának, minden dolog normák alá rendelésének és felügyeletének gyarkolatával, aminek eldologiasító és szubjektiváló erőszakosságát Foucault követte nyomon egészen a köznapi kommunikáció legfinomabb kapillárisaiig. A megrendszabályozott, széttagolt, ellenörzött és gondoskodással körülvett életvilág torzulásai nyilván szublimáltabbak, mint a materiális kizsákmányolás és elnyomorodás kézzelfogható formái, de a pszichikumra és a testre hárított, belsővé tett szociális konfliktusok nem kevésbé destruktívak. Röviden: a szociális állam tervezetében eleve benne rejlik a cél és a módszer közti ellentmondás.” Habermas: „A jóléti állam válsága és az utópikus energiák kimerülése”, 295-296.

${ }^{36}$ Habermas: I. m., 302-303.

37, ,[A]z Új Áttekinthetetlenség annak a szituációnak a része, amelyben a szociális állam még mindig a munkatársadalmi utópiából táplálkozó programja elveszti erejét egy kollektíve jobb és kevésbé veszélyeztetett élet jövőbeli lehetőségeinek feltárására." Habermas: „A jóléti állam válsága és az utópikus energiák kimerülése”, 290. 
Kaleidoscope

„A munkatársadalommal kapcsolatos utópikus tartalmak elbúcsúztatásával természetesen korántsem zárul le a történeti tudat és a politikai vita dimenziója. Ha kiszáradnak az utópia oázisai, a banalitás és a tanácstalanság sivataga nyer teret [kiemelés tölem - T. Á.]. Kitartok a mellett a tézisem mellett, hogy csakúgy, mint eddig - az az aktualitás-tudat merít a modern kor öntudatából, amelyben összeolvad a történeti és az utópikus gondolkodás. A munkatársadalom utópikus tartalmaival azonban eltünik két, a modernség öntudatát megbabonázó illúzió." 38

Összefoglalás

Habermas korunk egyik legnagyobb hatású filozófusa és társadalomteoretikusa, aki a 20. század második felétől explicite a Frankfurti Iskola kritikai elméletének megújításának szándékával lép fel. A filozófia és a társadalomtudományok doyenje egyaránt jártas az analitikus és kontinentális filozófiai áramlatokban. Rendkívül széles látókörü és roppant kritikai-elemző képességü teoretikust ismerhetünk fel benne, aki még 90 éves korában is képes volt írni egy új megközelítésü, majd’ kétezer oldalas nyugati filozófiatörténetet. Die Neue Unübersichtlichkeit (Új Áttekinthetetlenség) c. 1985-ben napvilágot látott társadalmi problémákat diagnózisszerüen feltáró könyve behatóan vizsgálja a kései kapitalizmusban megtapasztalható válságjelenségeket, amiket a nyugat-európai jóléti állam belső ellentmondásoktól terhelt és egyre inkább fenntarthatatlan társadalmi modelljének neoliberális átalakítása csak tovább mélyített. Habermas könyve a globalizálódó nyugat-európai társadalmak szocio-kulturális keresztmetszete, ami egyszerre tesz kísérletet a szociális állam célja és módszere közt feszülő kibékíthetetlen ellentmondások bemutatására ( $A$ jóléti állam válsága és az utópikus energiák kimerülése ${ }^{39}$, mint ahogyan ideológiakritikailag elemzi a posztmodern építészetet, szociológus módjára ábrázolja az újkonzervatívok felemelkedését (Újkonzervativizmus), de találkozhatunk itt kifejezetten németspecifikus problémákkal (Még egy terhes örökség), aktuálpolitikai események analízisével ('83 ösze, avagy a jog morális neutralizálása), kultúrkritikai esszékkel (A felvilágosodás variánsai), mint ahogy konkrét politikai állásfoglalásokkal is (Tisztázások). Nem feledkezhetünk meg azonban elméletírói munkásságának társadalmi beágyazottságáról, ami az 1980-as évektől kezdődően már inkább nevezhető a liberális értékhorizontot és társadalompolitikai alapvetéseket eurocentrikusan univerzalizáló, a nyugati racionalizmust és az észszerüségen alapuló demokratikus döntéshozást hangsúlyozó rendszerapologetikájáról, ami mindenfajta túlzás nélkül nevezhető az Európai Unió idealisztikus metafizikájának, mintsem egy, jelenünk architektonikájának föbb törésvonalait elsődlegesen rögzíteni kívánó társadalomtudós megvilágító erejű kordiagnózisának.

Habermas kései korszakának főbb elméleteiben a status quót fenntartó, a filozófia fősodrával, és nem azzal szemben úszó „bebiztosított kriticizmusa” Adornóék metsző társadalom- és rendszerkritikáját „szalonképesen” kerekíti le, a politikafilozófiai radikalizmust pedig reformjavaslatokká és jogiadminisztratív korrektívumokká csillapítja. Elméletírása maga sem térhet ki a reflexió elöl, melynek legfőbb kritikusa nem az akadémiai miliő, hanem a habermasi teóriát megcáfoló praxis nyers valósága (pl. Brexit, az EU nem hatékony konfliktuskezelési potenciálja, a kelet-európai térséget csak retorika szintjén felzárkóztató, valójában Nyugat és Kelet közt kvázi-koloniális függőséget fenntartó gazdaságpolitikája, stb.). A „kényszermentes egyetértés” illetve „torzítatlan interszubjektivitás” kulcsmozzanatait magába foglaló kommunikativitás-elmélet alapvetően konszenzust kereső, nem pedig szociálisan érzékeny politikafelfogást képvisel. Habermas affirmatív kommunikatív cselekvéselméletével szemben radikálisan szemben áll a politikai kevésbé idealisztikus felfogása, amit a posztmarxista teoretikusok (Laclau, Chantal Mouffe, Rancière) képviselnek, miszerint a politikai horizontot szociális antagonizmusok, a társadalmi problémákból fakadó disszenzus és általános többnézőpontúság képzik meg és formálják azt. Mindazonáltal Habermas müveit már csak filozófiai-társadalomelméleti jelentőségük miatt sem szabad teljességgel

\footnotetext{
${ }^{38}$ Habermas: I. m., 306.

${ }^{39}$ A továbbiakban a német nyelvü kötet fejezetcímeit magyarra fordítva tüntetem fel. http://www.kaleidoscopehistory.hu Tillmann Ármin
} 
Kaleidoscope

figyelmen kívül hagyni, az olvasó feladata sokkal inkább az, hogy müveihez minden esetben egyfajta egészséges, kritikai-reflektív szkepszissel közelítsen.

Hivatkozott irodalom:

ADORNO, Theodor W.: Esztétikai elmélet. Fordította: Teller Katalin. Kiadatlan kézirat.

Jean BAUDRILLARD: „A szimulákrum elsőbbsége”. In (szerk.: Kis Attila Atilla, Kovács Sándor, Odorics Ferenc): Testes könyv I. Fordította: Gángó Gábor. Szeged: JATE - Ictus 1992, 161-194.

BAUDRILLARD, Jean: „Az orgia után”. In: A Rossz transzparenciája. Esszé a szélsőséges jelenségekröl. Fordította: Klimó Ágnes. Budapest: Balassi Kiadó - BAE Tartóshullám - Intermédia 1997, 9-17.

BLOCH, Ernst: Az utópia szelleme. A második (1923-as) fogalmazvány átdolgozott kiadása. Fordította: MESTERHÁZI Miklós. Budapest: Gond - Cura Alapítvány 2007.

CASTORIADIS, Cornelius: Gesellschaft als imaginäre Institution. Entwurf einer politischen Philosophie. Fordította: Horst Brühmann. Frankfurt am Main: Suhrkamp 1990.

CORNFORTH, Maurice: A nyílt filozófia és a nyillt társadalom. Hogyan cáfolta meg dr. Karl Popper a marxizmust?. Fordította: Sós Vilmos. Budapest: Gondolat 1975.

DEBORD, Guy: A spektákulum társadalma. Fordította: Erhardt Miklós. Budapest: Balassi Kiadó - BAE Tartóshullám 1992

FUKUYAMA, Francis: A történelem vége és az utolsó ember. Fordította: Somogyi Pál László. Budapest: Európa 1994.

HABERMAS, Jürgen: „A jóléti állam válsága és az utópikus energiák kimerülése”. In: Válogatott tanulmányok. Fordította: Adamik Lajos, Bendl Júlia, Felkai Gábor. Budapest: Atlantisz 1994, 283-308.

HABERMAS, Jürgen: „Egy befejezetlen projektum - a modern kor”. In: Jürgen Habermas - Jean-François Lyotard - Richard Rorty: A posztmodern állapot. Fordította: Nyizsnyánszky Ferenc. Budapest: Századvég 1993, 151-178.

HABERMAS, Jürgen: „Moderne und postmoderne Architektur”. In: Die Neue Unübersichtlichkeit. Kleine Politische Schriften V. Frankfurt am Main: Suhrkamp 1985, 11-29.

JAMESON, Fredric: „A kései kapitalizmus kulturális logikája”. In: A posztmodern, avagy a kései kapitalizmus kulturális logikája. Fordította: Dudik Annamária Éva. Budapest: Noran 2010, 23-72.

JAMESON, Fredric: „A posztmodern elméletei”. In: A posztmodern, avagy a kései kapitalizmus kulturális logikája. Fordította: Dudik Annamária Éva. Budapest: Noran 2010, 73-84.

JAMESON, Fredric: „Térbeli megfigyelők a világrendszerben”. In: A posztmodern, avagy a kései kapitalizmus kulturális logikája. Fordította: Dudik Annamária Éva. Budapest: Noran 2010, 114-141.

KISS, Endre: „A posztmodern gondolkodás rekonstrukciója”. In: Globalizáció és/vagy posztmodern. (Tanulmányok a jelen elméletéről). Főiskolai jegyzet. Budapest/Székesfehérvár: Kodolányi János Főiskola 2003, 76-81.

KISS, Endre: „Kísérlet a posztmodern empíriáról”. In: Globalizáció és/vagy posztmodern. (Tanulmányok a jelen elméletéről). Főiskolai jegyzet. Budapest/Székesfehérvár: Kodolányi János Főiskola 2003, 198-202. LUKÁCS, György: Az ész trónfosztása. Az irracionalista filozófia kritikája. Budapest: Akadémiai Kiadó 1974.

MANNHEIM, Károly: Ideológia és utópia. Fordította: Mezei I. György. Budapest: Atlantisz 1996.

MÁRKUS, György: „A kultúra társadalma - a kulturális modernitás konstitúciója”. In: Kultúra, tudomány, társadalom. A kultúra modern eszméje. Fordította: Lánczi András. Budapest: Atlantisz 2017, $27-52$.

WELLMER, Albrecht: „A modern és posztmodern dialektikája. Az észkritika Adorno után”. In: A modern és posztmodern dialektikája. Az észkritika Adorno után. Fordította: Weiss János. Budapest: Gond - Cura Alapítvány 2008, 63-150. 